\title{
PERTANGGUNGJAWABAN KORPORASI DALAM TINDAK PIDANA LINGKUNGAN HIDUP
}

\author{
THE CORPORATE LIABILITY IN ENVIRONMENTAL CRIMES
}

\author{
Idi Amin \\ Fakultas Hukum Universitas Mataram \\ email : aminidi@yahoo.com
}

Naskah diterima : 10/07/2018; direvisi : 08/08/2018; disetujui : 11/08/2018

\begin{abstract}
This research title is the corporate liability in the environmental crimes, the problem in this research is how the corporate criminal responsibility which conduct the environmental crimes. The purpose of this research is to know and analyze the problem above. The method in this research is normative method. The result shows that the criminal liability principle on corporation which conduct the environmental crimes is liability based on fault principle, shortly can be said that it adopt the principle of mistake or culpability.
\end{abstract}

\section{Keywords : corporate, responsibility, living environment}

\begin{abstract}
Abstrak
Penelitian ini berjudul pertanggungjawaban korporasi dalam tindak pidana lingkungan hidup, adapun masalah yang ingin dikaji adalah bagaimana bentuk pertanggungjawaban pidana terhadap kooporasi yang melakukan tindak pidana lingkungan hidup. Sedangkan tujuan dari penelitian ini adalah untuk mengetahui dan menganalisa permasalahan diatas. Untuk mencapai penelitian tersebut peneliti menggunakan penelitian hukum normatif. Hasil penelitian menunjukkan bahwa Prinsip yang dianut dalam pertanggungjawaban pidana terhadap korporasi yang melakukan tindak pidana lingkungan hidup adalah prinsip liability based on fault (pertanggungjawaban pidana berdasarkan kesalahan), yang secara singkat dapat dikatakan menganut asas kesalahan atau culpabilitas.
\end{abstract}

Kata Kunci : Korporasi, Pertanggungjawaban, Lingkungan Hidup.

\section{PENDAHULUAN}

Perkembangan perundang-undangan khusus di luar KUHP, khususnya tentang subyek hukum pidana, yaitu korporasi perumusannya lebih luas dibandingkan dengan pengertian korporasi menurut hukum perdata, menurut hukum pidana pengertian korporasi bisa berbentuk badan hukum atau tidak. ${ }^{1}$

Dalam hukum lingkungan, badan hukum juga diterima sebagai subyek

\footnotetext{
${ }^{1}$ Muladi, Dwija Priyatno, Pertanggungjawaban Korporasi Dalam Hukum Pidana, Sekolah Tinggi Hukum Bandung, 2002, hlm. 21.
}

hukum. Hal ini karena di samping hal tersebut merupakan tuntutan perkembangan masyarakat, juga karena yuridis telah diakui dan diatur dalam Undang-Undang No. 23 Tahun 1997 Tentang Pengelolaan Lingkungan Hidup. ${ }^{2}$

Dalam tulisan ini, pertanggungjawaban pidana terhadap pelaku tindak pidana lingkungan hidup, berorientasi pada Undang-Undang No. 23 Tahun 1997 tentang Pengelolaan Lingkungan Hidup

\footnotetext{
${ }^{2}$ Setiyono, Kejahatan Korporasi, Analisis Viktimologis dan PertanggungJawaban Korporasi Dalam Pidana Indonesia, Averroes Press, Malang, 2002, hlm. 12.
} 
(UUPLH) sebagai pengganti UndangUndang No. 4 Tahun 1982 karena undang-undang inilah yang merupakan Undang-undang Payung bagi semua perundang-undangan yang mengatur tentang lingkungan hidup di Indonesia.

Selain itu, undang-undang lingkungan sektoral yang diatur dalam UndangUndang No. 5 Tahun 1983 tentang ZEE Indonesia, Undang-Undang No. 5 Tahun 1984 tentang Perindustrian, UndangUndang No. 5 Tahun 1990 tentang Konservasi Hayati, Undang-Undang No. 21 Tahun 1992 tentang Pelayaran.

Dalam Pasal 1 sub 24 Undang-Undang No. 23 tahun 1997 tentang Pengelolaan Lingkungan Hidup, dikemukakan bahwa yang dimaksud dengan "orang" sebagai subyek hukum dari pidana lingkungan hidup adalah "perseorangan dan atau kelompok orang dan atau badan hukum". Kemudian dalam Bab IX tentang Ketentuan Pidana tercantum dalam Pasal 45 dan Pasal 46 yang mengatur tentang pertanggungjawaban badan hukum berupa perseroan, persekutuan, yayasan atau organisasi lain.

Dari ketentuan di atas, dapat ditarik suatu pengertian bahwa di samping orang atau perseorangan, badan hukum dapat menjadi subyek tindak pidana lingkungan hidup dan dipertanggungjawabkan.

Berdasarkan uraian di atas fokus artikel ini akan membahas tentang bentuk pertanggungjawaban pidana korporasi yang melakukan tindak pidana lingkungan hidup .

Penelitian ini merupakan penilitian normatif, yang menggunakan pendekatan perundang-undangan dan pendekatan konseptual. Statute approach adalah pendekatan yang beranjak dari peraturan perundang-undangan di mana dalam penelitian ini mencakup konvensikonvensi internasional ${ }^{3}$ serta undang-

\footnotetext{
${ }^{3}$ Erlies Septiana. Nurbani, Perkembangan Teknologi Senjata dan Prinsip Proporsionalitas, Jurnal Ius Kajian Hukum dan Keadilan, Volume 5 Nomor 12017 hlm 1329. DOI : http://dx.doi.org/10.29303/ius.v5i1.436
}

undang nasional yang berkaitan dengan permasalahan yang dihadapi. Conceptual approach adalah pendekatan yang beranjak pada pandangan-pandangan dan doktrindoktrin. Dengan mempelajari pandanganpandangan dan doktrin-doktrin peneliti akan menemukan ide-ide yang melahirkan pengertian-pengertian, konsep-konsep dan asas-asas hukum yang relevan dengan isu yang dihadapi. Pemahaman atas pandangan-pandangan dan doktrindoktrin tersebut merupakan sandaran bagi peneliti dalam membangun suatu argumentasi hukum guna memecahkan permasalahan yang dihadapi. ${ }^{4}$

\section{PEMBAHASAN}

Berdasarkan perundang-undangan yang telah disebutkan di depan, dapat diklasifikasikan sistem pertanggungjawaban hukum pidana terhadap Pelaku Tindak Pidana Lingkungan Hidup (TPLH) sebagai berikut : ${ }^{5}$

\section{Subyek Yang Dapat Dipertanggung- jawabkan}

Perumusan secara eksplisit, bahwa badan hukum merupakan subyek hukum terlihat antara lain di dalam perumusan Pasal 6 ayat (1), Pasal 7 ayat (1) dan Pasal 10 ayat (1) Undang-Undang No. 9 tahun 1985 tentang Perikanan. Delik yang terkait dengan Pasal 6 ayat (1) dan Pasal 7 ayat (1) itu dirumuskan dalam Pasal 24, dan yang terkait dengan Pasal 10 ayat dirumuskan dalam Pasal 25 dan Pasal 26 UU No. 9 tahun 1985. Didalam Pasal 21 ayat (1) jo. Pasal 1 ke-7 UU No. 5 Tahun 1984 tentang Perindustrian, badan hukum sebagai subyek tindak pidana dirumuskan secara eksplisit, yaitu dengan menyebut Perusahaan Industri sebagai Pelaku Tindak Pidana.

\section{Pertanggungjawaban Pidana Ber- dasarkan Kesalahan \\ ${ }^{4}$ Ibid. \\ ${ }^{5}$ Barda Nawawi Arief, Masalah Penegakan Hukum dan Kebijakan Penanggulangan Kejahatan, Citra Aditya Bakti, Bandung, 2001, hlm. 105}


Dengan adanya tanggung jawab berdasarkan kesalarahan (liability base on fault) dapat diartikan bahwa tanggung jawab tersebut timbul pada saat terjadinya pencemaran lingkungan dan atau perusakan sumber daya alam, tak dapat dielakkan lagi dan secara prosedural tidak diperlukan upaya pembuktian lagi. Kewajiban ini melekat pada barang siapa yang melakukan perbuatan, tidak melakukan perbuatan tetapi membiarkan terjadinya pencemaran dan kerusakan daya alam. ${ }^{6}$

Ketentuan pidana mengenai Tindak Pidana Lingkungan Hidup tercantum dalam Bab IX UUPLH yang terdiri dari Pasal 41 sampai dengan Pasal 48. Apabila dibandingkan dengan ketentuan pidana yang tercantum dalam Pasal 22 UndangUndang Lingkungan Hidup (UULH), ketentuan pidana dalam UUPLH jauh lebih lengkap dan rinci.

Ancaman pidana sebagaimana tercantum dalam pasal-pasal UUPLH adalah pidana penjara dan denda, berbeda dengan ancaman pidana UULH yang meliputi pidana penjara dan/atau denda. Sebagaimana juga Pasal 22 UULH, delik yang diatur dalam Pasal 41 UUPLH adalah delik material.

Yang harus diperhatikan pula adalah bahwa ancaman pidana diperberat apabila tindak pidana mengakibatkan orang mati atau luka berat. Penetapan luka dilakukan oleh tenaga medis. Apabila Pasal 41 UUPLH adalah mengenai perbuatan dengan sengaja, maka Pasal 42 UUPLH adalah mengenai perbuatan karena kealpaan, yang ancaman pidananya lebih ringan.

Berbeda dengan Pasal 41 UUPLH yang mengandung delik materiil, Pasal 43 UUPLH memuat delik formil, yang lebih memudahkan pembuktian karena dikaitkan dengan deskripsi tindakan yang menimbulkan pencemaran dan/

\footnotetext{
${ }^{6}$ Andi Hamzah, Sistem Pidana dan Pemidanaan, Pradnya Paramita, Jakarta, 1993, hlm. 82.
}

atau perusakan lingkungan hidup dan membahayakan kesehatan umum atau nyawa orang lain.

Apabila dengandelik materiilsulituntuk membuktikan perbuatan pencemaran dan/atau perusakan lingkungan hidup, misalnya untuk membuktikan suatu usaja dan/atau kegiatan yang mencemarkan karena baku mutu ambien sungai telah dilampaui ambang batasnya padahal sumber pencemaran dapat berupa limbah industri, limbah domestik dan limbah pertanian, yang berarti multi source pollution, maka delik formil yang tercantum dalam Pasal 43 ayat (1) dikaitkan dengan melepaskan atau membuang zat, energi dan/atau komponen lain yang berbahaya dan beracun ke dalam air permukaan yang melanggar ketentuan perundangundangan.

Dengan demikian cukup dibuktikan bahwa usaha dan/atau kegiatan yang bersangkutan limbahnya melampaui ambang batas yang ditetapkan oleh baku mutu efluen, yang pengukurannya dapat dilakukan di tempat penggelontoran limbah.

Pasal 43 ayat (2) UUPLH memuat ancaman pidana bagi pemberian informasi palsu dan hal-hal lain yang berkaitan dengan informasi, yang dapat dihubungkan dengan hak atas informasi sebagaimana diatur dalam Pasal 5 ayat (2) UUPLH. Apabila Pasal 43 UUPLH mengatur tentang perbuatan dengan sengaja, maka Pasal 44 UUPLH dikaitkan dengan kealpaan, yang ancaman pidananya lebih ringan.

Berkaitan dengan tindak pidana lingkungan hidup yang dilakukan oleh suatu korporasi, dunia hukum pada saat ini melihat penghukuman yang terkait dengan proses kriminalisasi terhadap pelaku pidana korporasi ini.

Seperti yang telah diungkapkan di depan bahwa dalam UUPLH diatur juga tentang tanggung jawab korporasi, yaitu dalam Pasal 45 dan Pasal 46. Pasal 45 
UUPLH menyatakan bahwa jika tindak pidana sebagaimana dimaksud dalam Bab ini dilakukan oleh atau atas nama suatu badan hukum, perseroan, perserikatan, yayasan atau organisasi lain, ancaman pidana denda diperberat dengan sepertiga.

Pasal 46 UUPLH menyatakan:

1. Jika tindak pidana sebagaimana dimaksud dalam Bab ini dilakukan oleh atauatas namabadan hukum, perseroan, perserikatan, yayasan atau organisasi lain, tuntutan pidana dilakukan dan sanksi pidana serta tindakan tata tertib sebagaimana dimaksud dalam Pasal 47 dijatuhkan baik terhadap badan hukum, perseroan, perserikatan, yayasan atau organisasilaintersebutmaupunterhadap mereka yang memberi perintah untuk melakukan tindak pidana tersebut atau yang bertindak sebagai pemimpin dalam perbuatan itu atau terhadap keduaduanya.

2. Jika tindak pidana sebagaimana dimaksud dalam Bab ini dilakukan oleh atau atas badan hukum, perseroan, perserikatan, yayasan atau organisasi lain, dan dilakukan oleh orang-orang, baik berdasar hubungan kerja maupun berdasarkan hubungan lain, yang bertindak dalam lingkungan badan hukum, perseroan, perserikatan, yayasan atau organisasi lain, tuntutan pidana diberlakukan dan sanksi pidana dijatuhkan terhadap mereka yang memberi perintah atau yang bertindak sebagai pemimpin tanpa mengingat apakah orang tersebut, baik berdasar hubungan kerja atau hubungan lain, melakukan tindak pidana secara sendiri atau bersama-sama.

3. Jika tuntutan dilakukan terhadap badan hukum, perseroan, perserikatan, yayasan atau organisasi lain, panggilan untukmenghadapdanpenyerahansuratsurat panggilan itu ditujukan kepada pengurus di tempat tinggal mereka, atau ditempatpengurusmelakukanpekerjaan yang tetap.
4. Jika tuntutan dilakukan terhadap badan hukum, perseroan, perserikatan, yayasan atau organisasi lain, yang pada saat penuntutan diwakili oleh bukan pengurus, hakim dapat memerintahkan agar pengurus menghadap sendiri di pengadilan.

Konsekuensi penerapan ketentuan tentang tanggung jawab korporasi ini harus benar-benar dipahami oleh para pengusaha, sehingga harus hati-hati dalam mengelola perusahaannya agar tidak melakukan perbuatan yang mengakibatkan pengusaha dikenakan pidana penjara, di samping perusahaannya dikenakan denda, karena telah terjadi pencemaran dan/atau perusakan lingkungan hidup yang diakibatkan oleh usaha dana/atau kegiatannya itu.

Pasal 47 UUPLH menyatakan bahwa selain ketentuan pidana sebagaimana dimaksud dalam KUHP dan Undangundang ini, terhadap pelaku tindak pidana lingkungan hidup dapat pula dikenakan tata tertib berupa :

1. Perampasan ketentuan yang diperoleh dari tindak pidana, dan/atau

2. Penutupan seluruhnya atau sebagian perusahaan, dan/atau

3. Perbaikanakibattindakpidana,dan/atau 4. Mewajibakan mengerjakan apa yang dilalaikan tanpa hak, dan/ atau

5. Menempatkan perusahaan di bawah pengampuan paling lama 3 (tiga) tahun. Sedangkan dalam Pasal 48 UUPLH menyatakan bahwa tindak pidana sebagaimana dimaksud dalam Bab ini adalah kejahatan. Penerapan ketentuan pidana perlu memperhatikan asas subsidaritas sebagaimana tercantum dalam penjelasan umum UUPLH, yaitu sebagai berikut :

Sebagai penunjang hukum administrasi, berlakunya ketentuan hukum pidana hendaknya didayagunakan apabila sanksi perdata, dan alternatif penyelesaian sengketa lingkungan hidup tidak efektif dan/atau tingkat kesalahan pelaku relatif 
Idi Amin | Pertanggungjawaban Korporasi Dalam Tindak Pidana Lingkungan Hidup.

berat dan/atau akibat perbuatannya relatif besar dan/atau perbuatannya menimbulkan keresahan masyarakat.

Wewenang diskresi yang ada pada jaksa untuk tidak memberlakukan ketentuan hukum pidana diberikan rambu-rambu sebagaimana tercantum di atas. ${ }^{7}$

\section{SIMPULAN}

Prinsip yang dianut dalam pertanggungjawaban pidana terhadap korporasi yang melakukan tindak pidana lingkungan hidup adalah prinsip liability based on fault (pertanggungjawaban pidana berdasarkan kesalahan), yang secara singkat dapat dikatakan menganut asas kesalahan atau culpabilitas.

Jika merujuk pada ketentuan dalam Pasal 46 yang mencamtumkan pertanggungjawaban pidana terhadap korporasi, hal ini merupakan suatu kemajuan dibandingkan dengan Undang-Undang Nomor 4 Tahun 1982. Namun belum dapat ditentukan apakah pertanggungjawaban badan hukum dalam Pasal 46 Undang-Undang Nomor 23 Tahun 1997 tersebut dapat berlaku juga untuk semua tindak pidana lingkungan hidup yang lain. Seharusnya dalam aturan peralihan Undang-Undang ini dicantumkan hal bahwa Pasal 46 tersebut dapat berlaku umum untuk semua tindak pidana limgkungan hidup di luar UndangUndang Nomor 23 Tahun 1997.

\section{DAFTAR PUSTAKA}

Andi Hamzah, 1993. Sistem Pidana dan Pemidanaan, Pradnya Paramita, Jakarta.

Barda Nawawi Arief, 2001. Masalah Penegakan Hukum dan Kebijakan Penanggulangan Kejahatan, Citra Aditya Bakti, Bandung.

Nurbani, E. S. 2017. PERKEMBANGAN TEKNOLOGI SENJATA DAN

\footnotetext{
${ }^{7}$ Koesnadi Hardjosoemitro, Hukum Tata Lingkun gan, Gajah Mada University Pers, Yogyakarta, 2002, hlm. 413.
}

PRINSIP PROPORSIONALITAS. Jurnal IUS Kajian Hukum dan Keadilan, 5(1), 13-29. DOI : http://dx.doi.org/10.29303/ius. v5i1.436

Koesnadi Hardjosoemitro, 2002. Hukum Tata Lingkungan, Gajah Mada University Pers, Yogyakarta.

Muladi, Dwija Priyatno, 2002. Pertanggungjawaban Korporasi Dalam Hukum Pidana, Sekolah Tinggi Hukum Bandung, Bandung.

Setiyono, 2002. Kejahatan Korporasi, Analisis Viktimologis dan PertanggungJawaban Korporasi Dalam Pidana Indonesia, Averroes Press, Malang.

Undang-undang No. 23 Tahun 1997 Tentang Pengelolaan Lingkungan Hidup. 